\title{
ISSUES IN THE USE OF THE EVENT STUDY METHODOLOGY: AN ANALYSIS OF MARKETING STRATEGIES IN PRODUCT RECALL STUDIES
}

\author{
OLAY ÇALIŞMASI YÖNTEMİNIN KULLANILDIĞI KONULAR: ÜRÜN \\ GERİ ÇAĞIRMA ÇALIŞMALARINDA PAZARLAMA STRATEJILERININN \\ BÍR ANALİŻ
}

\author{
Fatma Hilal ERGEN KELES ${ }^{*}$ \\ Burç ÜLENGİN ${ }^{*}$
}

\begin{abstract}
Event study methodology, which relies on market efficiency, investigates stock price changes after an event. Despite this methodology arises in the finance literature, it found a wide execution area including the marketing literature. Event study makes it possible to observe the effect of diverse marketing activities on financial value and is therefore very suitable for understanding marketingfinance interface. Empirical findings of product recall studies suggest that a product recall cause to a decrease the firm value. Furthermore, product recall studies adopt event studies that help better understand the reactions of the investors to different marketing strategies in a crisis context. However, only limited studies are available in this field. This paper covers (1) an instruction an instruction of the methodology, (2) a review that highlights the implementations of the method in the marketing literature, (3) summary of studies that measure the effect of marketing strategies in the product recall context, and (4) propositions for further empirical testing. We aim to guide further empirical studies.
\end{abstract}

Keywords: Event study methodology, product harm crises, product recall, marketing strategy

JEL Classification: G14, H12, M31

Özet

Piyasa etkinliğine dayanan olay çalışması yöntemi, bir olay sonrası gerçekleşen hisse senedi fiyat değişimlerini incelemektedir. Bu yöntem finans literatüründe ortaya çıkış olmasına rağmen, kendine pazarlama literatürü de dâhil olmak üzere geniş bir uygulama alanı bulmuştur. Olay çalışması çeşitli

* Dr., Marmara University, Faculty of Business Administration, Department of Business (German), Göztepe, Kadıköy, İstanbul, Corresponding Author, fergen@marmara.edu.tr, Orcid Id: 0000-0002-3914-6459

* Professor Dr., İstanbul Technical University, Faculty of Management, Department of Management Engineering, Maçka, Beşiktaş, İstanbul, ulenginbur@itu.edu.tr, Orcid Id: 0000-0001-5276-8861 
pazarlama faaliyetlerinin bir firmanın finansal değeri üzerindeki etkilerini gözlemlemeye imkân vermektedir ve bu nedenle pazarlama-finans ara yüzünü anlamak için oldukça uygundur. Ürün geri çağırma konusunu inceleyen çalışmaların ampirik bulguları bir ürün geri çağırmanın firmanın değerinde düşüşe neden olacağını ortaya koymaktadır. Bununla birlikte, ürün geri çağırma çalışmaları yatırımcıların kriz ortamındaki farklı pazarlama stratejilerine yönelik tepkilerini daha iyi anlamalarına yardım eden olay çalışmalarını kullanmaktadır. Buna karşın, bu alanda oldukça sınırlı sayıda çalışma bulunmaktadır. Bu çalışma, (1) olay çalışması yönteminin açıklamasını, (2) pazarlama literatüründe ilgili yöntemin başlıca uygulamalarını gösteren bir taramayı, (3) ürün geri çağırma konusu kapsamında pazarlama stratejilerinin etkisini inceleyen çalışmalarının özetini, ve (4) ileride yapılabilecek olan ampirik çalışmalarda yol göstermesi amaçlanan önerileri kapsamaktadır.

Anahtar Kelimeler: Olay çalışması yöntemi, ürün hasar krizleri, ürün geri çağırma, pazarlama stratejisi

JEL Sınıflandırması: G14, H12, M31

\section{Introduction}

The event study methodology investigates the financial effect of an event based on the stock prices. The methodology is based on the concept of market efficiency that publicly available information immediately update the security prices after it is announced. This method is beneficiary the immediate price movement in the stock will show an event's impact under the market rationality assumption $^{1}$. The assumption of rapid change in the prices makes the methodology especially interesting because it allows to isolate the effect of other factors and to determine the impact of the related action(s) or event(s). However data of other financial performance metrics (eg. ROI, ROE, return on sales) is available at a low frequency (eg. monthly, annually).

Studies investigating the impact of an event on firm value have emerged in Finance researches first. Dolley ${ }^{2}$, known to be first to use event study, explore the effect of stock splits on the price. More sophisticated research was conducted later, however, this methodology as its use in today first presented by Ball and Brown in the study earning announcements in terms of information content were examined ${ }^{3}$, whereas Fama, Fisher, Jensen and Roll in their study examined the effect of stock splits on the prices by using event study ${ }^{4}$. Some studies have modified the basic methodology of this two papers. Among them, Brown and Warner ${ }^{5}$ and Boehmer, Musumeci and Poulsen ${ }^{6}$ added important modifications. They present the way to use event studies, introduce

MacKinlay, A. C. (1997). Event Studies in Economics and Finance, Journal of Economic Literature, 35(1): 13-39.

Dolley, J. C. (1933). Characteristics and Procedure of Common Stock Split-ups, Harvard Business Review, 11(3): 316-326.

3 Ball, R., Brown, P. (1968). An Empirical Evaluation of Accounting Income Numbers, Journal of Accounting Research, 159-178.

4 Fama, E. et al. (1969). The Adjustment of Stock Prices to New Information. International Economic Review, 10(1), $1-21$.

5 Brown, S. J., Warner, J. B. (1980). Measuring Security Price Performance. Journal of Financial Economics, 8(3), 205-258.

6 Boehmer, E., et al. (1991). Event-Study Methodology under Conditions Of Event-Induced Variance. Journal Of Financial Economics, 30(2), 253-272. 
use of longer data sets (monthly) and two separate windows: estimation and event windows ${ }^{7}$. Additionally they include different models where returns are adjusted by using mean, market performance or risk (beta). However, event study format has been the same with FFJR ${ }^{8}$.

Event study approach is not only been used in various fields of accounting and finance ${ }^{9}$; but also in diverse areas as management ${ }^{10}$, law $^{11}$, economics ${ }^{12}$, and operations systems ${ }^{13}$ and marketing ${ }^{14}$.

This methodology enables researchers to examine the widespread effects on firm value. It also provides evidence related to immediate response of stock prices to information ${ }^{15}$. Hence, Fama ${ }^{16}$ considers event studies as the test of market efficiency and source of our knowledge in corporate finance. Fama ${ }^{17}$ describes markets as efficient that security prices reflect always the existing information. Therefore, prices should change in response to newly arrived information.

Papers using event study in the marketing literature are mainly focusing on corporate firm announcements, and these papers generally investigate the expected positive reactions of investor to positive marketing actions. On the other hand, studies on marketing actions or events (e.g. product recalls) that may have a negative effect on financial value are considerably less. In this article, an overview of event study papers in the marketing literature is given and then the product recall studies applying event study methodology are examined. All studies are concerned with the product recall context and investigate the impact of diverse marketing strategies on financial value when firms are confronted with a recall. Therefore, an analysis of these papers shows how the topic is handled in previous researches, and prepares a ground for future studies.

7 Binder, J. (1998). The Event Study Methodology since 1969. Review of Quantitative Finance And Accounting, 11(2), 111-137.

8 Kothari, S. P., et al. (2007). Econometrics of Event Studies. Handbook of Empirical Corporate Finance, 1, 3-36.

9 Campbell, J. Y. et al. (1997). The Econometrics of Financial Markets, Princeton, NJ: Princeton University Press.

10 Koh, J., Venkatraman, N. (1991). Joint Venture Formations and Stock Market Reactions: An Assessment in the Information Technology Sector. Academy of Management Journal, 34(4), 869-892.

11 Davidson, W. et al. (1994) Stock Market Reactions To Announced Corporate Illegalities. Journal of Business Ethics, 13, 979-987.

12 Greenstone, M. et al. (2006). Mandated Disclosure, Stock Returns, and the 1964 Securities Acts Amendments. The Quarterly Journal of Economics, 121(2), 399-460.

13 Subramani, M., Walden, E. (2001). The Impact of E-Commerce Announcements on the Market Value of Firms. Information Systems Research, 12(2), 135-154.

14 Chen, Y. et al. (2009). Does A Firm's Product-Recall Strategy Affect Its Financial Value? An Examination of Strategic Alternatives during Product-Harm Crises. Journal of Marketing, 73(6), 214-226.

15 Fama, E. F. (1998). Market Efficiency, Long-Term Returns, and Behavioral Finance. Journal of Financial Economics, 49(3), 283-306.

16 Fama, E. F. (1991). Efficient Capital Markets: II. The Journal of Finance, 46(5), 1575-1617.

17 Fama, E. F. (1970). Efficient Capital Markets: A Review of Theory and Empirical Work. The Journal of Finance, 25(2), 383-417. 


\section{Event Study Methodology}

Event study aims to determine event-related stock returns. The method uses abnormal returns (AR) to measure the stock market response to the event. Abnormal returns are different from returns of normal days (so-called normal return). AR is deviation from the normal returns in periods surrounding the event and calculated as the difference between actual returns and expected returns as follows:

$$
A R_{\text {it }}=\frac{P_{\text {it }}-E\left(P_{\text {it }}\right)}{P_{\text {it }-1}}=R_{\text {it }}-E\left(R_{\text {it }}\right)
$$

In the formula, $P_{\text {it }}$ and $P_{\text {it }-1}$ denote the stock price of firm ${ }^{i}$ at time ${ }^{t}$ and ${ }^{t}-1$, respectively, whereas $E\left(R_{\text {it }}\right)$ expresses the expected stock returns of firm ${ }^{i}$ at period $\left({ }^{t}-1,{ }^{t}\right)$ derived in the absence of the event.

Event studies can be short - or long-term based on the measurement period of abnormal returns. Short-term event studies use daily stock data while long-term studies explore abnormal returns in longer windows.

Short-term event studies assuming that markets are efficient find evidences on the impact of the event in any immediate changes. An event study involves two basic windows: estimation and event. The regular stock returns are estimated over estimation window whereas event window covers beginning and ending dates to measure expected returns. In event studies, not only event days but also days surrounding the event are considered. Event or measurement window includes at least one day before the event to capture any leakage and next day of the event to account the diffusion of information among investors. Figure 1 depicts the windows in an event study as follows.

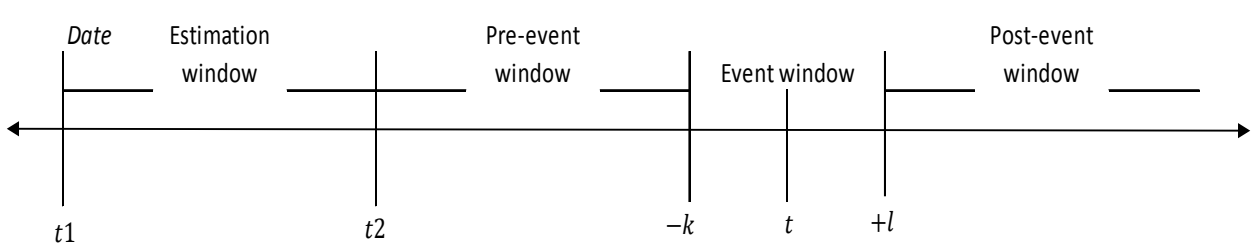

Figure 1: Event Study Timeline

When an event window is longer than one day, to calculate cumulative abnormal returns (CAR) daily abnormal returns are summed. The general formula for CAR that shows total change of firm value upon arrival of new information ${ }^{18}$ is below:

$$
C A R_{i}=\sum_{t-k}^{t+l} A R_{i t}
$$

18 Sorescu, A. et al. L. (2017). Event Study Methodology in the Marketing Literature: An Overview. Journal of the Academy Of Marketing Science, 45(2), 186-207. 
where $A R_{\text {it }}$ denotes abnormal return of stock $i$ on day ${ }^{t}$, whereas ${ }^{k}$ and $l$ represent the number of days prior to and following the related event, respectively. For example, CAR $(-1,-1)$ denotes abnormal returns for one day, the day before the event announcement, whereas CAR $(-1,1)$ shows cumulative abnormal returns covering the day before, the day and the next day of the event announcement.

The earlier methods to calculate short-term abnormal returns are based on Brown and Warner (1985)'s ${ }^{19}$ paper that use market and market-adjusted models to measure expected returns.

Market model

$$
E\left(R_{i t}\right)=R_{m t}
$$

where $E\left(R_{\mathrm{it}}\right)$ is the estimate of the expected stock return of firm $i$ and $R_{m t}$ is average market return at time $t$.

Market-adjusted model suggests that current market return is the best predictor of a firm's stock return. Hence, the only information to measure abnormal returns surrounding the event is available in the event period ${ }^{20}$.

Market-adjusted model

$$
E\left(R_{i t}\right)=R_{f t}+\beta_{i}\left(R_{m t}-R_{f t}\right)
$$

where $R_{f t}$ is the risk-free rate of return and $\beta_{i}$ is the risk estimate obtained from a regression over measurement windows.

Suggested by Fama, et al. market index model is basic asset pricing method used in event study methodology ${ }^{21}$. The method assumes linear relations between firm and market returns. In the model, the rate of return on stock $i$ over day $t$ is described as below:

Market index model

$$
R_{i t}=\alpha_{i}+\beta_{i} R_{m t}+\varepsilon_{i t}
$$

where $R_{\text {it }}$ denotes stock return of firm ${ }^{i}$ over day $\mathrm{t}, R_{m t}$ represents the return of a market portfolio over day $\mathrm{t}, \alpha$ and $\beta$ are intercept term and systematic risk of stock $i$, respectively. Finally, $\varepsilon_{\text {it }}$ is the disturbance term, $\varepsilon_{i t}=0$.

Calculation of the abnormal return for ${ }^{i}$ ts stock, is shown below:

Abnormal return

$$
A R_{\text {it }}=R_{\text {it }}-\left(\widehat{\alpha_{1}}+\widehat{\beta}_{1} R_{m t}\right)
$$

where $\widehat{\alpha}_{1}$ and $\widehat{\beta}_{1}$ are ordinary least squares (OLS) parameter estimates derived by regressing the actual (realized) rate of return on stock ${ }^{i}$ on an estimation period whereas $R_{\text {it }}$ is the return

19 Brown, S. J., Warner, J. B. (1985). Using Daily Stock Returns: The Case of Event Studies. Journal of Financial Economics, 14(1), 3-31.

20 Peterson, P. P. (1989). Event Studies: A Review of Issues and Methodology. Quarterly Journal of Business and Economics, 36-66.

21 Fama, E. F. et al., 1969. 
of the stock $i$ being adjusted for the risk factor of that stock. $A R_{i t}$ is abnormal return that is the significant difference between expected and realized return. The model is also known as OLS market model $^{22}$.

On the other hand, less marketing studies use longer event windows to calculate abnormal returns. Long-term event studies may concentrate on unexpected changes in firm-specific data in low frequency (quarterly or annual) whereas they may explore the impact of the event with additional information that will not be available in few days ${ }^{23}$.

Measurement of abnormal returns are different in long-term event studies from those of shortterm studies. Fama-French three-factor model, Carhart four-factor model, Buy-and-hold abnormal returns (BHARs) and Calender-time portfolios abnormal returns (CTARs) are assetpricing models used in long-term event studies. Fama and French ${ }^{24}$ suggest three-factor model including market risk, size and value factors (i.e., $\beta$ ). Carhart ${ }^{25}$. Formally,

\section{Carhart ff model}

$$
R_{i t}-R_{f t, t}=\alpha_{i}+\beta_{i}\left(R_{m t}-R_{f t, t}\right)+s_{i}\left(S M B_{t}\right)+h_{i}\left(H M L_{t}\right)+u_{i}\left(U M D_{t}\right)+\varepsilon_{i}
$$

where $R_{\text {it }}$ is stock return of firm $i$ at time $t, R_{f t, t}$ is risk-free rate of return in period $t$ and $R_{m t}$ is average market return in period $t$. As risk factors, $S M B_{t}$ denotes the difference between the return on a value-weighted portfolio of small stocks and the return on a value-weighted portfolio of big stocks, $H M L_{t}$ denotes the difference between the return on a value-weighted portfolio of high book-to-market stocks and the return on a value-weighted portfolio of low book-to-market stocks, and $U M D_{t}$ refers to the average return on two high prior-return portfolios minus the average return on two low prior-return portfolios.

BHARs are used to measure a firm's performance over one year or longer. They are calculated as the cumulative difference between compounded daily stock returns of firms' stock and of a benchmark portfolio that consists of similar stocks over one year or longer period.

Buy-and-hold abnormal returns (BHARs)

$$
B H A R_{i t}=\prod_{t=1}^{t=\tau}\left(1+R_{i t}\right)-\prod_{t=1}^{t=\tau}\left(1+R_{p(i t)}\right)
$$

22 Brown, S. J., Warner, J. B., 1985.

23 Sorescu, A. et al., 2017.

24 Fama, E. F., French, K. R. (1993). Common Risk Factors in the Returns on Stocks and Bonds. Journal of Financial Economics, 33(1), 3-56.

25 Carhart, M. M. (1997). On Persistence in Mutual Fund Performance. The Journal of Finance, 52(1), 57-82. 
Daniel, Grinblatt, Titman and Wermers ${ }^{26}$ suggests event firms' characteristics as size and bookto-market ratio whereas Bessembinder and Zhang ${ }^{27}$ associates BHAR with past returns, volatility and capital investment.

Among others, abnormal returns of Calender-Time Portfolios, shortly CTARs, are the most common metrics in long-term event studies to measure abnormal returns. As a first stage, similar firms are added at event time and grouped into portfolios. Then firms are hold in the portfolios during the length of estimation window ranging from six months to some years. Finally, portfolio returns are regressed over firm characteristics.

Calender-time abnormal returns (CTARs)

$$
R_{p t}-R_{f t}=\alpha_{p}+\beta_{p}\left(R_{m t}-R_{f t}\right)+\beta_{1}\left(S M B_{p t}\right)+\beta_{2}\left(H M L_{p t}\right)+\beta_{3}\left(U M D_{p t}\right)
$$

where, $R_{p t}$ denotes the actual portfolio return and $S M B_{p t}, H M L_{p t}$ and $U M D_{p t}$ are risk factors from two models, in month $t$ for the portfolio of event-firms, measured over $T$ months. The intercept $\alpha_{p}$ expresses the estimated average monthly abnormal return of the portfolio of eventfirms over the $T$-month post-event period. One can derive annual abnormal returns from multiplying the intercept by $12^{28}$.

While BHARs lead to high cross-sectional correlation by inflating t-statistics, CTARs automatically account for these correlations. In the latter method, standard error of $\alpha_{p}$ is computed from intertemporal variation of portfolio returns, hence supports market efficiency more than former where standard errors are computed within the cross-section. However, the power of CTARs method to detect abnormal performance is less since it averages over months of "hot" and "cold" event activity ${ }^{29}$. Return measure is unique for entire grouped portfolio; therefore, the method works better in continuous events rather than discrete ${ }^{30}$.

\section{Use of Event Studies in Marketing}

Afterwards, event studies find also use in marketing. The event study methodology is applied to catch the effects of diverse marketing events on firm value. This helps to predict the influence of marketing actions on financial value. Sorescu, et al. claims that our knowledge related to the

26 Daniel, K. et al. (1997). Measuring Mutual Fund Performance with Characteristic-Based Benchmarks. The Journal of Finance, 52(3), 1035-1058.

27 Bessembinder, H., Zhang, F. (2013). Firm Characteristics and Long-Run Stock Returns after Corporate Events. Journal of Financial Economics, 109(1), 83-102.

28 Sorescu, A. et al., 2017.

29 Loughran, T., Ritter, J. R. (2000). Uniformly Least Powerful Tests of Market Efficiency. Journal of Financial Economics, 55(3), 361-389.

30 Srinivasan, S., Hanssens, D. M. (2009). Marketing and Firm Value: Metrics, Methods, Findings, and Future Directions. Journal of Marketing Research, 46(3), 293-312. 
impact of marketing on firm financial value stems from event studies and their statement shows the suitability and importance of the methodology for the marketing literature ${ }^{31}$.

A sample of event studies in marketing literature is shown in Table 1. We see that, source of the event announcements could be the company, an agency, a competitor, a regulatory and/ or the ministry. For instance, product recalls are announced by the company, ministry and/ or regulatory, e.g. Toyota recall because of Takata airbags is announced by the company and regulatory. A firm can announce its entry in a new market, which will affect existing firms in the market, e.g. Walmart's entry in the UK.

Depending on the research aim, different lengths of event windows and measurement types of AR are applied in the marketing literature. Mostly short-term event windows are used, because the short-term abnormal return allows isolating the effect of other variables that could occur in the longer run. However, long-term studies also appear in the literature ${ }^{32}$. Furthermore, some studies combine short and long periods. Liu, Shankar, and Yun investigate the effect of crisis management strategies on financial value considering both periods since these strategies impact can change during the periods ${ }^{33}$.

Event study research in marketing includes (but not limited) firm announcement topics such as brand acquisitions ${ }^{34}$, corporate brand name changes ${ }^{35}$, innovation and/or new product ${ }^{36}$, marketing alliances ${ }^{37}$, channel expansion ${ }^{38}$, etc. Findings of these studies show that investors react generally positive to this kind of firm announcements. Nevertheless, studies show that announcements like entry of a competitor to the market, product recall noticed by the company, competitor and/or regulatory have a negative impact on financial value.

31 Sorescu, A. et al., 2017.

32 Sorescu, A. et al. (2007). Why Some Acquisitions Do Better Than Others: Product Capital As A Driver Of LongTerm Stock Returns. Journal of Marketing Research, 44(1), 57-72.

33 Liu, Y. et al. (2017). Crisis Management Strategies and the Long-Term Effects of Product Recalls on Firm Value. Journal of Marketing, 81(5), 30-48.

34 Wiles, M. A. et al. (2012). The Effect of Brand Acquisition and Disposal on Stock Returns. Journal of Marketing, 76(1), 38-58.

35 Kalaignanam, K., Bahadir, S. C. (2013). Corporate Brand Name Changes and Business Restructuring: Is The Relationship Complementary Or Substitutive?. Journal of the Academy Of Marketing Science, 41(4), 456-472.

36 Sood, A., Tellis, G. J. (2009). Do Innovations Really Pay Off? Total Stock Market Returns to Innovation. Marketing Science, 28(3), 442-456.

37 Swaminathan, V., Moorman, C. (2009). Marketing Alliances, Firm Networks, and Firm Value Creation. Journal of Marketing, 73(5), 52-69.

38 Homburg, C. et al. (2014). Firm Value Creation through Major Channel Expansions: Evidence from an Event Study in the United States, Germany, and China. Journal of Marketing, 78(3), 38-61. 
Table I: Event Study Examples in Marketing

\begin{tabular}{|c|c|c|c|c|c|}
\hline Info source & Author & News theme & $\begin{array}{l}\text { Sign of the } \\
\text { effect }\end{array}$ & \begin{tabular}{|l}
$\begin{array}{l}\text { Estimation of } \\
\text { expected returns }\end{array}$ \\
\end{tabular} & $\begin{array}{l}\text { Length of event } \\
\text { window }\end{array}$ \\
\hline Company & Elberse (2007) & Casting & + & $\begin{array}{l}\text { Constant-mean-return } \\
\text { model } \\
\text { Market model }\end{array}$ & $\begin{array}{l}\text { Short term } \\
(-7,0)\end{array}$ \\
\hline Company & $\begin{array}{l}\text { Wiles, et al. } \\
(2012)\end{array}$ & $\begin{array}{l}\text { Brand acquisition } \\
\text { Brand disposal }\end{array}$ & $\begin{array}{l}+ \\
+\end{array}$ & Market model & Short term $(0,1)$ \\
\hline Company & $\begin{array}{l}\text { Homburg, et } \\
\text { al. (2014) }\end{array}$ & Channel expansion & + & Market model & \begin{tabular}{|l|} 
Short term \\
$(-1,0)$
\end{tabular} \\
\hline Company & $\begin{array}{l}\text { Borah and } \\
\text { Tellis (2014) }\end{array}$ & $\begin{array}{l}\text { Make new product } \\
\text { Buy new product } \\
\text { Ally (to design/market) }\end{array}$ & $\begin{array}{l}+ \\
- \\
+\end{array}$ & Fama-French-Carhart & $\begin{array}{l}\text { Short term } \\
(-1,1)\end{array}$ \\
\hline Agency & $\begin{array}{l}\text { Tellis and } \\
\text { Johnson } \\
(2007)\end{array}$ & Product evaluation & + & $\begin{array}{l}\text { Market-adjusted } \\
\text { model }\end{array}$ & $\begin{array}{l}\text { Short term } \\
(-5,5)\end{array}$ \\
\hline Competitor & \begin{tabular}{|l}
$\begin{array}{l}\text { Gielens, et al. } \\
(2008)\end{array}$ \\
\end{tabular} & Competitor entry & - & Market model & Short term $(0,1)$ \\
\hline Regulatory & $\begin{array}{l}\text { Sorescu, et al. } \\
(2007)\end{array}$ & Merger and acquisition & $\begin{array}{l}{ }^{\circ} \text { for } \\
\text { acquirers } \\
+ \text { for target } \\
\text { firms } \\
\end{array}$ & BHARs & $\begin{array}{l}\text { Long term } \\
1-2 \text { year }\end{array}$ \\
\hline \multirow{3}{*}{ Company } & \begin{tabular}{|l}
$\begin{array}{l}\text { Chen, et al. } \\
(2009)\end{array}$ \\
\end{tabular} & Product recall & - & Market model & $(0,0)$ \\
\hline & \begin{tabular}{|l} 
Gao, et al. \\
$(2015)$
\end{tabular} & Product recall & - & Market model & $(-1,1)$ \\
\hline & $\begin{array}{l}\text { Eilert, et al. } \\
\text { (2017) }\end{array}$ & Product recall & - & $\begin{array}{l}\text { Fama-French four- } \\
\text { factor model }\end{array}$ & $(-2,2)$ \\
\hline
\end{tabular}

\section{Effect of Marketing Strategies in Product Recall Context: Event Study Applications}

Product harm crisis is defined as a discrete and publicized event after it is figured out that a product has a defect and/or is dangerous ${ }^{39}$. A product harm crisis generally lead to a product recall. The absence of required quality in any step of the manufacturing and/or design process can affect all of the manufactured products in this product line ${ }^{41}$. After a product failure is realized, it may cause a product recall when the product (1) has a defect which potentially can harm consumers seriously,

39 Siomkos, G., Kurzbard, G. (1994). The Hidden Crisis in Product-Harm Crisis Management. European Journal of Management, 28(2), 30- 41.

40 Dawar, N., \& Pillutla, M. N. (2000). Impact of Product-Harm Crises on Brand Equity: The Moderating Role of Consumer Expectations. Journal of Marketing Research, 37(2), 215-226.

41 Chao, G. H. et al. (2009). Quality Improvement Incentives And Product Recall Cost Sharing Contracts. Management Science, 55(7), 1122-1138. 
(2) involves dangerous material(s) which could create vigorous exposure to consumers, (3) has the potential to injure or lead to death and (4) violates standards and/or regulations ${ }^{42}$.

Shortly, product recalls occur when products are considered as dangerous due to any defect. Today, product recalls are significantly increasing worldwide in all industries. According to Reuters, product recalls in the automobile industry hit a record in the US with 53.2 million recalled products in $2016^{43}$. Increase in product recalls are attributed to several reasons such as rise in product complexity, consumer expectations related to safety and quality, globalization of production. Additionally, a number of companies and government agencies observe closely ${ }^{44}$ 45 , increased quantity of production, limited production times, competitive pressure, etc. ${ }^{46}$, the extended, more complex and more global supply chains ${ }^{47}$. It is estimated that all of these trends will proceed in the future, meaning that product recalls will continue ${ }^{48}$.

Possible damaging consequences of product recalls for companies are summarized as follow:

- The costs of recalling, satisfying the legal responsibility, restoring the damaged firm reputation, providing a remedy ${ }^{49}$.

- The remedy cost including logistic, repair, readjustment of the production line, and communication costs ${ }^{50}$.

- Decreased market value and damaged brand equity of the firm in the longer term ${ }^{51}$.

- Declined future sales and correspondingly future profits, due to the negative perceptions and/or beliefs about the brand and the product and safety/health concerns ${ }^{52}$.

42 Chu, T. H. et al. (2005). An Extension of Security Price Reactions around Product Recall Announcements. Quarterly Journal of Business and Economics, 33-48.

43 https:/www.reuters.com/article/us-usa-autos-recall/u-s-auto-recalls-hit-record-high-53-2-million-in-2016idUSKBN16H27A, 20.11.2017.

44 Berman, B. (1999). Planning for the Inevitable Product Recall. Business Horizons, 42(2), 69-78.

45 Laufer, D., Jung, J. M. (2010). Incorporating Regulatory Focus Theory in Product Recall Communications to Increase Compliance with a Product Recall. Public Relations Review, 36(2), 147-151

46 Beamish, P. W., Bapuji, H. (2008). Toy Recalls and China: Emotion vs. Evidence. Management and Organization Review, 4(2), 197-209.

$47 \mathrm{Ni}$, J. Z. et al. (2014). Impact of Product Recall Announcements on Retailers' Financial Value. International Journal of Production Economics, 153, 309-322.

48 Chen, Y., Nguyen, N. H. (2013). Stock Price And Analyst Earnings Forecast Around Product Recall Announcements. International Journal of Economics and Finance, 5(6), 1.

49 Hora, M. et al. (2011). Safety Hazard and Time to Recall: The Role Of Recall Strategy, Product Defect Type, And Supply Chain Player In The U.S. Toy Industry. Journal of Operations Management, 29(7), 766-777.

50 Souiden, N., Pons, F. (2009). Product Recall Crisis Management: The Impact on Manufacturer's Image, Consumer Loyalty and Purchase Intention. Journal of Product \& Brand Management, 18(2), 106-114.

51 Chu, T. H. et al., 2005.

$52 \mathrm{Ni}$, J. Z. et al., 2014. 
- Destroyed investor confidence, leading to a decrease in funding supply of current or potential investors ${ }^{53}$.

- $\quad$ Negatively affected share prices of firms after a product recall announcement ${ }^{54}$.

Event study methodology enables to measure the impact of product recalls on financial performance based on stock return data. This also enables (1) to gain empirical papers through real-life cases which could help to reinforce theory and empirics, (2) to consider the effect of product recalls on financial value (so not limited with the consumer perspective) by considering the investor community and contribute to marketing-finance interface. In the finance and marketing literature, it is proven that product recalls influence firm's financial value negatively. Besides, studies in the marketing literature seek for the ways to minimize the negative effect of product recalls. Table 2 presents an overview of product recall papers that adopt event studies in marketing.

All studies in Table 2;

- $\quad$ based on the efficient market hypothesis,

- focus on investors in some cases also firms are taken into consideration as in the papers of Thirumalai and Sinha ${ }^{55}$ and Eilert, et al. ${ }^{56}$, and

- define the dependent variable as firm value, which is proxied by abnormal and/or cumulative abnormal returns, some of the papers formulate additional dependent variables such as Thirumalai and Sinha ${ }^{57}$ - number of recalls, Eilert, et al. ${ }^{58}$ - time to recall.

Despite there are some studies examining the implications of marketing strategies in product recall situation, research in this area is still rare.

53 Chen, Y. et al., 2009.

54 Jarrell, G., Peltzman, S. (1985). The Impact of Product Recalls on the Wealth of Sellers. Journal of Political Economy, 93(3), 512-536.

55 Thirumalai, S., Sinha, K. K. (2011). Product Recalls in the Medical Device Industry: An Empirical Exploration of the Sources and Financial Consequences. Management Science, 57(2), 376-392.

56 Eilert, M. et al. (2017). Does It Pay To Recall Your Product Early? An Empirical Investigation in the Automobile Industry. Journal of Marketing, 81(3), 111-129.

57 Thirumalai, S., Sinha, K. K., 2011.

58 Eilert, M. et al., 2017. 
Table 2: Product Recall Studies in the Marketing Literature Using Event Study Methodology

\begin{tabular}{|c|c|c|c|}
\hline Authors & $\begin{array}{l}\text { Event } \\
\text { Window }\end{array}$ & Topic - Issue & Findings \\
\hline $\begin{array}{l}\text { Chen, et al. } \\
\text { (2009) }\end{array}$ & {$[0,0]$} & $\begin{array}{l}\text { The effects of proactive vs. } \\
\text { passive recall strategies on } \\
\text { financial value }\end{array}$ & $\begin{array}{l}\text { Proactive strategies can harm more than passive } \\
\text { alternatives. } \\
\text { Investors may read proactive strategy message as } \\
\text { a signal of financial loss for the company. } \\
\text { Financial markets may evaluate the moves of the } \\
\text { company managing proactive recall process as } \\
\text { the efforts to minimize the financial damage of } \\
\text { a crisis. }\end{array}$ \\
\hline $\begin{array}{l}\text { Thirumalai } \\
\text { and Sinha } \\
(2011)\end{array}$ & $\begin{array}{l}{[-10} \\
+1]\end{array}$ & $\begin{array}{l}\text { Empirical testing whether } \\
\text { the financial effects of } \\
\text { recalls of medical equipment } \\
\text { make medical companies } \\
\text { to remove dangerous } \\
\text { equipment from the market } \\
\text { as proposed in the literature } \\
\text { Also impact of firm } \\
\text { characteristics are taken into } \\
\text { consideration }\end{array}$ & $\begin{array}{l}\text { Financial market are not significantly sensitive as } \\
\text { expected at the aggregate level. } \\
\text { However, firm characteristics such as product } \\
\text { scope, sales, expected growth, and the capital } \\
\text { structure of a company have an influence on } \\
\text { financial outcomes. } \\
\text { R\&D-oriented, diverse product portfolio-holder } \\
\text { companies are likely to have higher recalls while } \\
\text { past recalls might be followed by less subsequent } \\
\text { recalls. }\end{array}$ \\
\hline $\begin{array}{l}\text { Gao, et al. } \\
(2015)\end{array}$ & {$[0,+1]$} & $\begin{array}{l}\text { The impact of pre-recall } \\
\text { advertising spending as } \\
\text { proactive strategy to limit } \\
\text { the stıck market loss. }\end{array}$ & $\begin{array}{l}\text { Increasing pre-recall advertising spending for } \\
\text { a new product with a minor hazard (an older } \\
\text { product with a major hazard) diminishes } \\
\text { (magnifies) financial loss. } \\
\text { Furthermore, reducing pre-recall advertising } \\
\text { spending is financially depressing for newly } \\
\text { introduced products. }\end{array}$ \\
\hline $\begin{array}{l}\text { Hsu and } \\
\text { Lawrence } \\
\text { (2016) }\end{array}$ & {$[-1,+1]$} & $\begin{array}{l}\text { The negative effects of social } \\
\text { media on firm value during } \\
\text { product recall } \\
\text { Moderating effect of brand } \\
\text { equity, participating in } \\
\text { online platforms on the } \\
\text { relation of online word-of- } \\
\text { mouth } \\
\text { (WOM) and recall. }\end{array}$ & $\begin{array}{l}\text { Most WOM variables amplify negative effect of } \\
\text { recall on companies' abnormal returns. } \\
\text { The higher the brand equity of a company is the } \\
\text { lower negative effect social media has. } \\
\text { No effect of online participation on the negative } \\
\text { impact of social during recall. }\end{array}$ \\
\hline $\begin{array}{l}\text { Eilert, et } \\
\text { al. (2017) }\end{array}$ & $\begin{array}{l}\text { During } \\
\text { After }\end{array}$ & $\begin{array}{l}\text { The impact of problem } \\
\text { severity on time to recall by } \\
\text { moderating effect of brand } \\
\text { characteristics } \\
\text { Financial market response to } \\
\text { time to recall }\end{array}$ & $\begin{array}{l}\text { Problem severity leads to rise in time to recall, } \\
\text { The effect is lower for reliable and experienced } \\
\text { (severe recall) companies while it is higher for the } \\
\text { companies that have brand diversification. } \\
\text { Stock markets consider the product recall timing } \\
\text { by reacting negatively to delays. }\end{array}$ \\
\hline $\begin{array}{l}\text { Liu, et al. } \\
\text { (2017) }\end{array}$ & $\begin{array}{l}{[-2,+2]} \\
1 \text { year } \\
\text { after }\end{array}$ & $\begin{array}{l}\text { Long-term impacts of recall } \\
\text { volume on financial value } \\
\text { Moderating effect of crisis } \\
\text { management strategies on } \\
\text { this relation }\end{array}$ & $\begin{array}{l}\text { There is a negative effect of recall volume } \\
\text { on financial value and recall remedy efforts } \\
\text { moderate this effect. } \\
\text { Besides, financial value is positively affected } \\
\text { by brand advertising and voluntary recall, and } \\
\text { negatively by promotional advertising. }\end{array}$ \\
\hline
\end{tabular}




\section{Research Propositions}

Because of the increase in product recall numbers and the expectation of that the increase will continue companies should be aware how to react in such crisis. Previously gained research shows that the negative impact of product harm crisis on financial value could be reduced by adopting diverse marketing strategies in different product recall cases. This sets a meaningful way for further investigations. Despite it is known that marketing communication contribute to corporate identity ${ }^{59}$ and that corporate identity could affect organizational performance - including financial performance - the product recall literature lacks at the communication area. Communication could be engaged as a strategic tool for crises management. Stocker $(1997)^{60}$ defines crisis management as "the preparation and application of strategies and tactics that can prevent or modify the impact of major events on the company or organization". The overall aim of crisis management can be summarized as to prevent or lessen the negative consequences of a crisis ${ }^{61}$ and communication is one of the fundamental components of a crisis management process. Crisis communication process covers the dialogue of the organization with its stakeholders before, during, and after the crisis ${ }^{62}$. Crisis communication functions can be summarized as providing information to stakeholders and protect and maintain the firm, such as its image, reputation, financial performance, etc.

Besides the existent knowledge in the minds of investors, the intention and/or plan expression of companies in a harm crisis would affect their reactions just as any information have influence on consumers' views regarding the firms ${ }^{63}$.

Accordingly, propositions are stated below.

Communication strategy through a product recall crisis could influence investors' evaluations.

A crisis could cause to uncertainty and increase in uncertainty lowers investment ${ }^{64}$. A detailed enlightenment given by the company could resolve uncertainty which could lower the negative effect a product recall.

P1: The more information is given, the more positive reaction investors give.

59 Markwick, N., Fill, C. (1997). Towards a Framework For Managing Corporate Identity. European Journal of Marketing, 31(5/6), 396-409.

60 Stocker, K. P. (1997). A Strategic Approach to Crisis Management. C. L. Caywood (Ed.). In The Handbook of Strategic Public Relations \&Integrated Communications, Boston, MA: Mcgraw Hill, 1997, 189-203.

61 Coombs, W. T. (2015). Ongoing Crisis Communication: Planning, Managing, and Responding. Thousand Oaks, CA: Sage.

62 Fearn-Banks, K. (2007), Crisis Communications: A Casebook Approach, 3rd Ed., Mahwah, NJ: Lawrence Erlbaum Associates.

63 Cornelissen, J. (2000). Corporate Image: An Audience Centred Model. Corporate Communications: An International Journal, 5(2), 119-125.

64 Caballero, R. J. (1991). On The Sign of the Investment-Uncertainty Relationship. The American Economic Review, 81(1), 279-288. 
Expectation and perception could be influenced regarding to the information source in a crises situation ${ }^{65}$ therefore source of the product recall information could make a different impact on investors, i.e. more responsible perception if the company instead of regulatory announces the recall, if a company spokesperson is ready to inform affected automobile users, the public, regulators.

P2a: The effect of company based product recall announcement is more positive instead of an announcement made by other institutions.

P2b: There is a more positive effect if company spokesperson is ready to inform in a product recall event.

A corporate responsible firm should respect for the general publics and/or societies interests. A product recall could bring along diverse concerns involving humanity and environment. In these circumstances, it could be decisive to inform the public/the society about the harm.

P3a: The statement of whether there is no damage to environment in the recall or that the cause of the damage is removed reduce the negative investor effect.

P3b: The statement of whether there is no negative impact to the humanity in the recall or that the cause of the effect is removed leads to reduce the negative investor effect.

\section{Conclusion}

Product recalls can harm a company. Therefore, it is important to manage such crises. Right crisis management could help lessen the negative affect of a product recall. Despite a suitable communication strategy could be a potential help in a product harm crises especial empirical research in this area is rare.

In this paper, highlight key points of the event study methodology and the area of use of event studies in the marketing literature with a focus on product recalls are presented. Further step is to investigate the proposed relationships, which will provide empirical evidence for (1) communication, which can help as crisis management tool, (2) information cues such as information amount, source, and content in a product recall announcement that could change the view of investors. Further empirical testing of the propositions would help managers to apply the appropriate corporate communication strategy and formulate an optimum product recall announcement, which could lead to lessen the negative effect of the product recalls.

65 Austin, L. et al. (2012). How Audiences Seek Out Crisis Information: Exploring the Social-Mediated Crisis Communication Model. Journal of Applied Communication Research, 40(2), 188-207. 


\section{References}

AUSTIN, L., Fisher Liu, B., Jin, Y. (2012). How Audiences Seek Out Crisis Information: Exploring the SocialMediated Crisis Communication Model. Journal of Applied Communication Research, 40(2), 188207.

BALL, R., Brown, P. (1968). An Empirical Evaluation of Accounting Income Numbers. Journal of Accounting Research, 159-178.

BEAMISH, P. W., Bapuji, H. (2008). Toy Recalls and China: Emotion vs. Evidence. Management and Organization Review, 4(2), 197-209.

BERMAN, B. (1999). Planning For the Inevitable Product Recall. Business Horizons, 42(2), 69-78.

BESSEMBINDER, H., Zhang, F. (2013). Firm Characteristics and Long-Run Stock Returns after Corporate Events. Journal of Financial Economics, 109(1), 83-102.

BINDER, J. (1998). The Event Study Methodology since 1969. Review of Quantitative Finance and Accounting, 11(2), 111-137.

BOEHMER, E., Musumeci, J., Poulsen, A. B. (1991). Event-Study Methodology under Conditions of EventInduced Variance. Journal of Financial Economics, 30(2), 253-272.

BORAH, A., Tellis, G. J. (2014). Make, Buy, Or Ally? Choice Of and Payoff from Announcements of Alternate Strategies for Innovations. Marketing Science, 33(1), 114-133.

BROWN, S. J., Warner, J. B. (1980). Measuring Security Price Performance. Journal of Financial Economics, 8(3), 205-258.

BROWN, S. J., Warner, J. B. (1985). Using Daily Stock Returns: The Case of Event Studies. Journal of Financial Economics, 14(1), 3-31.

CABALlERO, R. J. (1991). On The Sign of the Investment-Uncertainty Relationship. The American Economic Review, 81(1), 279-288.

CAMPBELL, J. Y., Lo, A. W., Mackinlay, A. C. (1997). The Econometrics of Financial Markets, Princeton, NJ: Princeton University Press.

CARHART, M. M. (1997). On Persistence in Mutual Fund Performance. The Journal of Finance, 52(1), 57 82.

CHAO, G. H., Iravani, S. M. R., Savaskan, R. C. (2009). Quality Improvement Incentives And Product Recall Cost Sharing Contracts. Management Science, 55(7), 1122-1138.

CHEN, Y., Ganesan, S., Liu, Y. (2009). Does A Firm's Product-Recall Strategy Affect Its Financial Value? An Examination of Strategic Alternatives during Product-Harm Crises. Journal of Marketing, 73(6), 214-226.

CHEN, Y., Nguyen, N. H. (2013). Stock Price And Analyst Earnings Forecast Around Product Recall Announcements. International Journal of Economics and Finance, 5(6), 1.

CHU, T. H., Lin, C. C., Prather, L. J. (2005). An Extension of Security Price Reactions around Product Recall Announcements. Quarterly Journal of Business and Economics, 33-48.

COOMBS, W. T. (1995). Choosing the Right Words: The Development of Guidelines for the Selection of the "Appropriate" Crisis-Response Strategies. Management Communication Quarterly, 8(4), 447-476.

COOMBS, W. T. (2015). Ongoing Crisis Communication: Planning, Managing, and Responding. Thousand Oaks, CA: Sage.

CORNELISSEN, J. (2000). Corporate Image: An Audience Centred Model. Corporate Communications: An International Journal, 5(2), 119-125. 
DAWAR, N., Pillutla, M. N. (2000). Impact of Product-Harm Crises on Brand Equity: The Moderating Role of Consumer Expectations. Journal of Marketing Research, 37(2), 215-226.

DAVIDSON, W., Worrell, D., Lee, C. (1994) Stock Market Reactions To Announced Corporate Illegalities. Journal of Business Ethics, 13, 979-987.

DOLLEY, J. C. (1933). Characteristics and Procedure of Common Stock Split-Ups. Harvard Business Review, 11(3), 316-326.

DANIEL, K., Grinblatt, M., Titman, S., Wermers, R. (1997). Measuring Mutual Fund Performance with Characteristic-Based Benchmarks. The Journal of Finance, 52(3), 1035-1058.

DIESTRE, L., Rajagopalan, N. (2014). Toward An Input-Based Perspective on Categorization: Investor Reactions to Chemical Accidents. Academy Of Management Journal, 57(4), 1130-1153.

EILERT, M., Jayachandran, S., Kalaignanam, K., Swartz, T. A. (2017). Does It Pay To Recall Your Product Early? An Empirical Investigation in the Automobile Industry. Journal of Marketing, 81(3), 111-129.

ELBERSE, A. (2007). The Power Of Stars: Do Star Actors Drive The Success of Movies? Journal of Marketing, $71(4), 102-120$.

FAMA, E. F., Fisher, L., Jensen, M. C., Roll, R. (1969). The Adjustment of Stock Prices to New Information. International Economic Review, 10(1), 1-21.

FAMA, E. F. (1970). Efficient Capital Markets: A Review of Theory and Empirical Work. The Journal of Finance, 25(2), 383-417.

FAMA, E. F. (1991). Efficient Capital Markets: II. The Journal of Finance, 46(5), 1575-1617.

FAMA, E. F., French, K. R. (1993). Common Risk Factors in the Returns on Stocks and Bonds. Journal of Financial Economics, 33(1), 3-56.

FAMA, E. F. (1998). Market Efficiency, Long-Term Returns, and Behavioral Finance. Journal of Financial Economics, 49(3), 283-306.

FEARN-BANKS, K. (2007), Crisis Communications: A Casebook Approach, 3rd Ed., Mahwah, NJ: Lawrence Erlbaum Associates.

GIELENS, K., Van De Gucht, L. M., Steenkamp, J. B. E., Dekimpe, M. G. (2008). Dancing With A Giant: The Effect of Wal-Mart's Entry into the United Kingdom on the Performance of European Retailers. Journal of Marketing Research, 45(5), 519-534

GREENSTONE, M., Oyer, P., Vissing-Jorgensen, A. (2006). Mandated Disclosure, Stock Returns, and the 1964 Securities Acts Amendments. The Quarterly Journal of Economics, 121(2), 399-460.

HOMBURG, C., Vollmayr, J., Hahn, A. (2014). Firm Value Creation through Major Channel Expansions: Evidence from an Event Study in the United States, Germany, and China. Journal of Marketing, 78(3), 38-61

HORA, M., Bapuji, H., Roth, A. V. (2011). Safety Hazard and Time to Recall: The Role Of Recall Strategy, Product Defect Type, And Supply Chain Player In The U.S. Toy Industry. Journal of Operations Management, 29(7), 766-777.

HSU, L., Lawrence, B. (2016). The Role of Social Media and Brand Equity during a Product Recall Crisis: A Shareholder Value Perspective. International Journal of Research in Marketing, 33(1), 59-77.

JARRELL, G., Peltzman, S. (1985). The Impact of Product Recalls on the Wealth of Sellers. Journal of Political Economy, 93(3), 512-536.

KALAIGNANAM, K., Bahadir, S. C. (2013). Corporate Brand Name Changes And Business Restructuring: Is The Relationship Complementary Or Substitutive?. Journal of the Academy Of Marketing Science, 41(4), 456-472. 
KOH, J., Venkatraman, N. (1991). Joint Venture Formations and Stock Market Reactions: An Assessment in the Information Technology Sector. Academy of Management Journal, 34(4), 869-892.

KOTHARI, S. P., Warner, J. B. (2007). Econometrics of Event Studies. Handbook of Empirical Corporate Finance, 1, 3-36.

LAUFER, D., Jung, J. M. (2010). Incorporating Regulatory Focus Theory in Product Recall Communications to Increase Compliance with a Product Recall. Public Relations Review, 36(2), 147-151.

LEE, D. S., Mas, A. (2012). Long-Run Impacts of Unions on Firms: New Evidence from Financial Markets, 1961-1999. The Quarterly Journal of Economics, 127(1), 333-378.

LIU, Y., Shankar, V., Yun, W. (2017). Crisis Management Strategies and the Long-Term Effects of Product Recalls on Firm Value. Journal of Marketing, 81(5), 30-48.

LOUGHRAN, T., Ritter, J. R. (2000). Uniformly Least Powerful Tests of Market Efficiency. Journal of Financial Economics, 55(3), 361-389.

MACKINLAY, A. C. (1997). Event Studies in Economics and Finance. Journal of Economic Literature, 35(1), 13-39.

MCWILLIAMS, A., Siegel, D. (1997). Event Studies in Management Research: Theoretical and Empirical Issues. Academy Of Management Journal, 40(3), 626-657.

MARKWICK, N., Fill, C. (1997). Towards A Framework For Managing Corporate Identity. European Journal of Marketing, 31(5/6), 396-409.

NI, J. Z., Flynn, B. B., Jacobs, F. R. (2014). Impact of Product Recall Announcements on Retailers' Financial Value. International Journal of Production Economics, 153, 309-322.

PETERSON, P. P. (1989). Event Studies: A Review of Issues and Methodology. Quarterly Journal of Business and Economics, 36-66.

SIOMKOS, G., Kurzbard, G. (1994). The Hidden Crisis in Product-Harm Crisis Management. European Journal of Management, 28(2), 30- 41.

SOOD, A., Tellis, G. J. (2009). Do Innovations Really Pay Off? Total Stock Market Returns to Innovation. Marketing Science, 28(3), 442-456.

SORESCU, A., Chandy, R. K., Prabhu, J. C. (2007). Why Some Acquisitions Do Better Than Others: Product Capital As A Driver Of Long-Term Stock Returns. Journal of Marketing Research, 44(1), 57-72.

SORESCU, A., Warren, N. L., Ertekin, L. (2017). Event Study Methodology in the Marketing Literature: An Overview. Journal of the Academy Of Marketing Science, 45(2), 186-207.

SOUIDEN, N., Pons, F. (2009). Product Recall Crisis Management: The Impact on Manufacturer's Image, Consumer Loyalty and Purchase Intention. Journal of Product \& Brand Management, 18(2), 106114.

SRINIVASAN, S., Hanssens, D. M. (2009). Marketing and Firm Value: Metrics, Methods, Findings, and Future Directions. Journal of Marketing Research, 46(3), 293-312.

STOCKER, K. P. (1997). A Strategic Approach to Crisis Management. C. L. Caywood (Ed.). In The Handbook of Strategic Public Relations \&Integrated Communications, Boston, MA: Mcgraw Hill, 1997, 189-203.

SUBRAMANI, M., Walden, E. (2001). The Impact of E-Commerce Announcements on the Market Value of Firms. Information Systems Research, 12(2), 135-154.

SWAMINATHAN, V., Moorman, C. (2009). Marketing Alliances, Firm Networks, and Firm Value Creation. Journal of Marketing, 73(5), 52-69.

TELLIS, G. J., Johnson, J. (2007). The Value of Quality. Marketing Science, 26(6), 758-773. 
THIRUMALAI, S., Sinha, K. K. (2011). Product Recalls in the Medical Device Industry: An Empirical Exploration of the Sources and Financial Consequences. Management Science, 57(2), 376-392.

WILES, M. A., Morgan, N. A., Rego, L. L. (2012). The Effect of Brand Acquisition and Disposal on Stock Returns. Journal of Marketing, 76(1), 38-58.

YANG, S. B., Lim, J. H., Oh, W., Animesh, A., Pinsonneault, A. (2012). Research Note-Using Real Options to Investigate the Market Value of Virtual World Businesses. Information Systems Research, 23(3Part-2), 1011-1029.

YANG, H., Zheng, Y., Zaheer, A. (2015). Asymmetric Learning Capabilities and Stock Market Returns. Academy of Management Journal, 58(2), 356-374. 